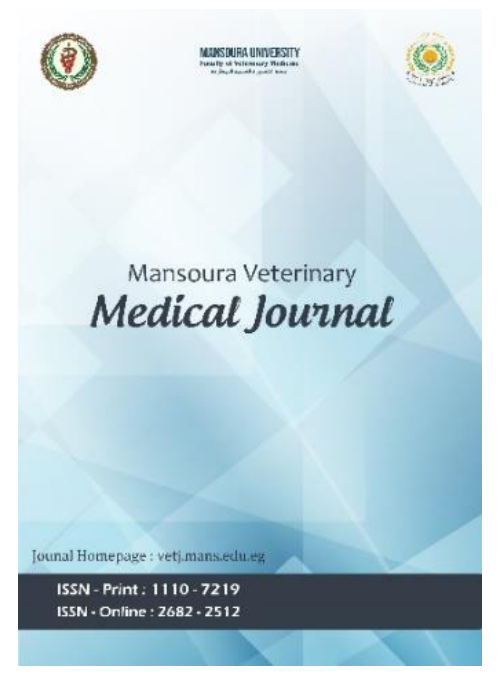

\title{
The protective effect of sulforaphane in rats fed on high cholesterol high fructose diets
}

\section{Wael El-Shahat, Mohamed EL-Adl, Mohamed Hamed, Youssef El-Saedy}

To cite this article: Wael El-Shahat, Mohamed EL-Adl, Mohamed Hamed, Youssef El-Saedy. The protective effect of sulforaphane in rats fed on high cholesterol high fructose diets. Mansoura Veterinary Medical Journal 2020; 21, 3: 85-90.

To link to this article: https://doi.org/10.35943/mvmj.2020.21.315

Published online: 29 September 2020

Submit your article to this journal

(Av) CrossMark data 


\title{
The protective effect of sulforaphane in rats fed on high cholesterol high fructose diets
}

\author{
Wael El-Shahat ${ }^{1}$, Mohamed EL-Adl ${ }^{1 *}$, Mohamed Hamed ${ }^{2}$, Youss ef El-Sa edy ${ }^{3}$ \\ ${ }^{1}$ Department of Biochemistry and Chemistry of Nutrition, Faculty of Veterinary Medicine, Mansoura University, P.O. 35516, Mansoura, Egypt. \\ 2Department of Pathology, Faculty of Veterinary Medicine, Mansoura University, P.O. 35516, Mansoura, Egypt. \\ ${ }^{3}$ Department of Physiology, Faculty of Veterinary Medicine, Mansoura University, P.O. 35516, Mansoura, Egypt.
}

\section{ARTICLE HISTORY}

Received: 12.02 .2020

Revised: 07.06.2020

Accepted: 15.06 .2020

Address correspondence to Mohamed El-

Adl; Tel: +201116209784; E-mail:

drmohamedalymaher@hotmail.com

\section{ABSTRACT}

Objective: To evaluate the protective role of sulforaphane in rats exposed to high cholesterol and high fructose diet.

Design: Randomized experimental study.

Animals: Twenty-four male Sprague Dawley rats.

Procedures: Rats were allocated in groups of six animals to one of four groups. The first group was kept as a control group in which rats were fed on a basal diet for 15 weeks (Control), while in the second group (Control + SFN) rats were fed on the basal diet for 11 weeks then a sulforaphane (SFN) was given $(0.5 \mathrm{mg} / \mathrm{kg} /$ day $)$ orally for additional 4 weeks. The third group was the high cholesterol high fructose (HCF) where rats were fed on the basal diet mixed with a solution of cholesterol $(1 \%)$ and fructose (10 \%) for 15 weeks, while in the fourth group (HCF + SFN) high cholesterol high fructose diet and sulforaphane rats were fed on the basal diet mixed with a solution of cholesterol $(1 \%)$ and fructose (10 \%) for 11 weeks then a SFN was given orally $(0.5 \mathrm{mg} / \mathrm{kg} /$ day $)$ for another 4 weeks. Serum and plasma samples were collected to determine the glycemic status, lipid profile, antioxidant status, oxidative and nitrosative stress markers, and apoptotic marker, alongside liver tissue samples for histopathological examination.

Results: Results revealed that sulforaphane alleviated the oxidative damage (decreasing MDA and NO) and improved the antioxidant status (reducing glutathione), and enhanced glycemic status through decreasing plasma glucose concentration and decreasing caspase 9 concentration.

Conclusion and clinical relevance: It can be suggested that sulforaphane (SFN) can improve insulin resistance (I.R) and improve serum lipid profile.

\section{INTRODUCTION}

Type 2 diabetes accounts for more than $90 \%$ of all cases of diabetes and is characterized by insulin resistance and a defect in insulin secretion from pa ncreatic ?]llells. The relative importance of al terations in insulin sensitivity versus secretion is debatable. It is accepted that hyperglycemia, hence diabetes, does not develop without allall dysfunction. Al teration of pancreatic 의] insulin secretory response to glucose is a hallmark of the transitionfrom the pre-diabetic to the diabetic state [1]. The el evated levels of cholesterol in hepatic tissues might lead to mitochondrial damage and eventually destruction in hepa tocytes [2]. Broccoli is one a mongthe few vegetables that is claimed to possess antidiabetic potency and is commonly consumed in India. It has a beneficial hypoglycemic influence in both experimental a nimals and humans through improving insulin resistance in type 2 diabetic patients [3]. Moreover, one of the hallmarks of type 2 diabetes is the exaggerated hepatic glucose production due to insulin resistance, other counteracting hormones will be increased in its activity stimulation gluconeogenesis. Sulforaphane (SFN), as an active principle of broccoli, has been suggested as a new potential anti-diabetic compound as it has a promising effect on hepatic glucose production [4]. However, the molecular principle of how SFN acts in different cell types is yet only partly understood. Therefore, the current study was conducted to evaluate the potential protective effect of SFN on glycemic status, lipid profile, antioxidant status, oxidative stress markers, a poptotic factor in rats received high cholesterol high fructose diets for 15 weeks.

\section{MATERIALS AND METHODS}

\subsection{Animals}

Twenty-four male Sprague Dawley rats were used in this study and were allocated into four groups (experimental treatments). Animals were housed in metal cages, where each cage contained six rats. They were supplied with a clean drinking water that was renewed every day, and a clean 
bedding material (sawdust) that was changed twice/week. Anima ls were left for accommodation for fourteen days prior to the induction of the experiment. The experimental protocol was approved by Research Ethics Committee, Faculty of Veteri nary Medicine, Mansoura University, Mansoura, Egypt.

\subsection{Chemicals}

Cholesterol powder used in the experiment was bought from Techo Pharmchem (Techo Pharmchem, Bahadurgarh, India). Fructose was obtained from El Gomhorya Company, (Egypt). Sulforaphane was obtained from MilliporeSigma (USA).

\subsection{Experimental design}

After accommodation, rats were al located in groups of six animals to one of the four following groups: the first group was kept as a control group (Group 1) in which a nimals were fed on a basal diet according to NRC, (1995) (Control). The second group (Group 2), incorporated rats fed on a basal diet for 11 weeks, in addition to an oral administration of a SFN $(0.5 \mathrm{mg} / \mathrm{kg} /$ day) [5] for a nadditional 4 weeks (Control + SNF). The third group (Group 3) included rats fed on a basal diet mixed with a solution of cholesterol $1 \%$ [6], a nd fructose $10 \%$ (HCF) [7] for 15 weeks. The fourth group (Group 4) included rats that fed on a basal diet mixed with a solution of cholesterol $1 \%$ and fructose $10 \%$ (HCF) for 11 weeks then a SFN was given $(0.5 \mathrm{mg} / \mathrm{kg} /$ day $)$ orally for another 4 weeks (Table 1).

\subsection{Collection of blood samples}

After 30 days of experimental induction, anesthesia of rats was induced and maintained with sodium thiopental (Pharco, Co, Egypt) $(20 \mathrm{mg} / \mathrm{kg}$ ) [8]. After rats were completely sedated, blood was drawn from heart through cardiac puncture in dry, clean, sterile and capped tubes that was left to clot, where clear serum sample was aspirated and transferred to clean Eppendorf for estimating serum leptin concentration [9], serum insulin concentration [10], serum total cholesterol (TC) concentration [11], serum HDLchol esterol (HDL-c) concentration [12], serum LDL-chol esterol (LDL-C) concentration [13] and serum triacylglycerol (TAG) concentration [14]. Other portion of the collected blood was transferred to clean test tubes containing sodium fluoride for determination of plasma glucose concentration [15].

\subsection{Tissue sampling}

After blood collection, animals were euthanized by cervical dislocation, then were dissected and liver was removed, washed by normal saline and divided into three parts. The first part was immersed in $10 \%$ neutral buffered formalin for histopathological examination according to Woods et al. [16]. The second part was homogenized in phosphate buffer saline ( $\mathrm{pH}$ 7.4) for determination of liver reduced glutathione concentration (GSH) [17], hepatic malondialdehyde (MDA) concentration [18], and hepatic nitric oxide (NO) concentration [19]. The third part of hepatic tissues was us ed to determine caspase 9 (cas 9) concentration using flow cytometry technique [20].

\subsection{Statistical analysis}

Data was analyzed using SPSS v.17. One-way ANOVA was used to test for the effect of experimental treatment (diet) with LSD as a post-hoc test at a significant level of 0.05. Data was expressed as means \pm standard errors [21].

Table 1. Formulated basal and high cholesterol diet used for rats throughout the study.

\begin{tabular}{|c|c|c|}
\hline \multicolumn{3}{|c|}{ For each $100 \mathrm{~kg}$} \\
\hline Food ingredients & $\begin{array}{l}\text { Number of } \\
\text { kilograms } \\
\text { (Basal diet) }\end{array}$ & $\begin{array}{l}\text { HC (high } \\
\text { cholesterol) }\end{array}$ \\
\hline Yellow corn & $70.6 \mathrm{~kg}$ & $70.2 \mathrm{~kg}$ \\
\hline Soya bean meal $40 \%$ & $23.3 \mathrm{~kg}$ & $23 \mathrm{~kg}$ \\
\hline Gluten $60 \%$ & $1.7 \mathrm{~kg}$ & $1.5 \mathrm{~kg}$ \\
\hline Corn oil & $975 \mathrm{ml}$ & $975 \mathrm{ml}$ \\
\hline Lime stone & $1.6 \mathrm{~kg}$ & $1.5 \mathrm{~kg}$ \\
\hline Sodium chloride & $300 \mathrm{gm}$ & $300 \mathrm{gm}$ \\
\hline Dibasic phosphate & $950 \mathrm{gm}$ & $950 \mathrm{gm}$ \\
\hline Premix & 350 gm & $350 \mathrm{gm}$ \\
\hline Sodium bicarbonate & $300 \mathrm{gm}$ & $300 \mathrm{gm}$ \\
\hline Anti-mycotoxin & $300 \mathrm{gm}$ & $300 \mathrm{gm}$ \\
\hline Cholesterol & $0 \mathrm{~kg}$ & $1 \mathrm{~kg}$ \\
\hline \multicolumn{3}{|c|}{$\begin{array}{l}\text { * Per } 1 \mathrm{~kg} \text { vitamin-mineral premix contains: } 12,000 \text { IU vitamin } A, 2,400 \\
\text { IU vitamin } D_{3}, 20 \mathrm{mg} \text { vitamin } \mathrm{E}, 4 \mathrm{mg} \text { vitamin } \mathrm{K}_{3}, 3 \mathrm{mg} \text { vitamin } B_{1}, 7 \mathrm{mg} \\
\left.\text { vitamin } B_{2}, 25 \mathrm{mg} \text { niacin (vit. } B_{3} \text { ), } 10 \mathrm{mg} \text { pantothenic acid (vit. } B_{5}\right), 5 \mathrm{mg} \\
\text { vitamin } B_{6}, 15 \mu \mathrm{g} \text { vitamin } B_{12}, 50 \mu \mathrm{g} \text { biotin, } 1 \mathrm{mg} \text { folic acid, } 50 \mathrm{mg} \\
\text { vitamin } \mathrm{C}, 100 \mathrm{mg} \mathrm{Mn}, 60 \mathrm{mg} \mathrm{Fe}, 60 \mathrm{mg} \mathrm{Zn}, 5 \mathrm{mg} \mathrm{Cu}, 2 \mathrm{mg} \mathrm{I}, 500 \mu \mathrm{g} \mathrm{Co} \text {, } \\
150 \mu \mathrm{g} \mathrm{Se} \text {. }\end{array}$} \\
\hline
\end{tabular}

\section{RESULTS}

Regarding the effect of Sulforaphane on the glycemic status of rats, serum levels of glucose and leptin increased in rats of HCF group, but decreased after treatment with SFN when compared to those of other groups. Moreover, serum insulin levels increased in rats of Control + HCF group compared to those of rats in the remaining groups, and decreased in rats of HCF group after trea tment with SFN when compared to other groups (Table 2).

Regarding the effect of Sulforaphane on the lipid profile of rats, rats of HCF group showed increased levels of serum TC, serum TAG, serum LDL-c, however these levels were decreased after treatment with SFN (Table 3). Rats of the HCF 
showed the lowest values for serum HDLc, and the highest values after treatment with SFN.

Rats of the HCF group displayed lower concentrations of hepatic GSH and NO compared to those in the Control and Control + SFN groups (Table 4). Treatment with SFN induced a marked increase in concentration of GSH and NO in rats of HCF group compared to those of HCF + NSF. Hepatic MDA concentrations were higher in rats of HCF group compared to those in the other groups. However, these high levels of MDA decreased after treatment with SFN (Table 4).

Table 2. Means \pm SEM Plasma glucose $(\mathrm{mmol} / \mathrm{L})$, serum insulin $(\mu \mathrm{IU} / \mathrm{ml})$ and serum leptin $(\mathrm{pg} / \mathrm{ml})$ in rats fed on basal (Control), basal and Sulforaphane (Control + SFN), high cholesterol high fructose (HCF), and high cholesterol high fructose supplemented with Sulforaphane (HCF + SFN) dietS

\begin{tabular}{|c|c|c|c|}
\hline Group & $\begin{array}{l}\text { Serum } \\
\text { glucose } \\
\text { mmol/L }\end{array}$ & $\begin{array}{l}\text { Serum insulin } \\
\mu \mathrm{lU} / \mathrm{ml}\end{array}$ & $\begin{array}{l}\text { Serum leptin } \\
\mathrm{pg} / \mathrm{ml}\end{array}$ \\
\hline Control & $4.42 \pm 0.09^{b}$ & $2.22 \pm 0.075^{b c}$ & $1.80 \pm 0.40^{c}$ \\
\hline Control + SFN & $4.29 \pm 0.16^{c}$ & $2.72 \pm 0.076^{a}$ & $1.80 \pm 0.115^{c}$ \\
\hline HCF & $13.80 \pm 0.46^{a}$ & $2.43 \pm 0.066^{a b}$ & $6.40 \pm 0.577^{a}$ \\
\hline $\mathrm{HCF}+\mathrm{SFN}$ & $6.43 \pm 0.42^{b}$ & $1.91 \pm 0.073^{c}$ & $3.66 \pm 0.176^{b}$ \\
\hline
\end{tabular}

In each column, means having different letters differ significantly

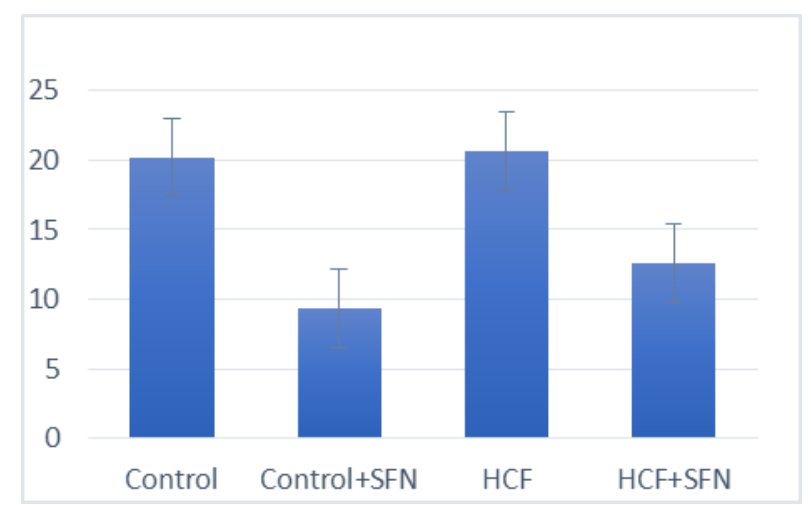

Figure 1. Flow cytometric assay of CAS 9 concentration in rats received basal (Control), basal and Sulforaphane (Control + SFN), high cholesterol high fructose (HCF), and high cholesterol high fructose supplemented with Sulforaphane $(\mathrm{HCF}+\mathrm{SFN})$ diets.

There was a significant reduction in hepatic concentrations of CAS 9 in rat's treated with SFN in both Control and HCF group (Figure 2). Results of the his topathological exa mination of hepatic tissue a re illus trated in Figure 2. In Figure 2A liver tissue displayed normal hepatocytes (arrow) in normal histological architecture with normal bloodvessels and normal hepatic sinusoids (HE, 400x). In Figure 2B, liver displayed normal hepatocytes (arrow) in normal ra dial a rrangement a round central vein (HE, 400x). In Figure $2 \mathrm{C}$, liver showed a massive hemorrhage replacing hepatic parenchyma with hepatocytes with a signet ring appearance (cytoplasm contains sharp clear vacuoles with pushed flattened nuclei to the cell membrane) (arrows) (HE, 100x). In Figure 2D, liver showed focal hepatocytes with a signet ring appearance. Moreover, there were focal lymphocytic infiltrates in hepatic parenchyma (arrow). (HE, 400x).

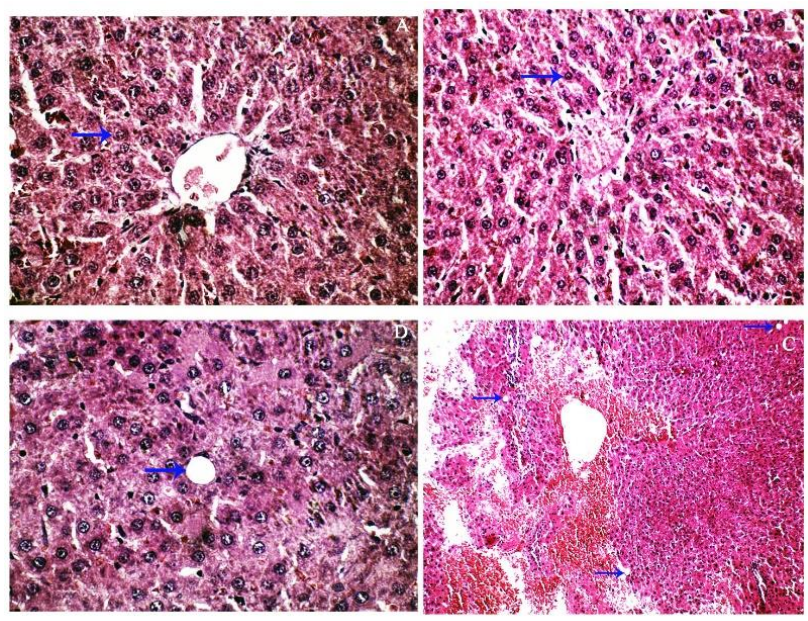

Figure 2. Histopathological examination of hepatic tissue in rats received basal (Control), basal and Sulforaphane (Control + SFN), high cholesterol high fructose (HCF), and high cholesterol high fructose supplemented with Sulforaphane (HCF + SFN) diets. (A) Hepatic tissue of rats in (Control), (B) Hepatic tissue of rats in SFN, (C) Hepatic tissue of rats in (HCF) and (D) Hepatic tissue of rats in (HCF $+\mathrm{SFN})$ group.

\section{DISCUSSION}

Numerous studies showed that insulin resistance precedes the development of hyperglycemia in subjects that eventually developed type 2 diabetes (T2D). However, it is increasingly being realized that T2D only develops in insulin resistant subjects with the onset of $\beta$ cell dysfunction [22]. Moreover, cholesterol loading on MIN6 cells derived from pancreatic $\beta$ cells leads to cholesterol-induced apoptosis in a time- and dose-dependent manner. Also, treatment with methyl- $\beta$-cyclodextrin that removes cholesterol from plasma membrane prevented the cells from cholesterol-induced apoptosis [23]. Sulforaphane (SFN) is an isothiocyanate derived from cruciferous vegetables such as broccoli and cabbage, and it plays a major role in energy metabolism [24].

HCF rats showed a significant impairment in glucose tolerance to exogenouslyadministered glucose, as shown by el eva ted glycemic levels at $60-120 \mathrm{~min}$ post gl ucose challenge, compared with the control group [25]. The molecular mechanism of SFN protection against diabetic nephropathy is through Nrf2 activation of antioxidant enzymatic defenses (NADPH-quinone oxireductase and c- glutamyl cysteine syntheta se) suggesting that this same pathway could exert an 
insulin-independent action in the reduction of blood glucose [26].

In addition, SFN has the potential to increase energy expenditure by enhancing uncoupling protein 1 (UCP1) expression in inguinal and epididymal adipose tissue depots [27]. Sulforaphane could also attenuate hyperglycemiainduced endothelial damage via inhibition of the mitochondrial ROS production and inactivation of the hexosamine and PKC pathways and protein glycation [28].

A threefold increase in insulin levels was detected in HCF rats, relative to controls [25]. In conclusion, Bahadoran et al. [3] mentioned that 4 weeks supplementation with broccoli sprout rich in SFN had favorable effects on decreasing serum insulin and improving IR in type 2 diabetes. Shawky et al. [29] revealed that fasting plasma insulin levels were higher by 2.1fold in high fructose and cholesterol fed rats when compared to those of the control group. This may indicate a dys function of adipose tissue in maintaining a ppropriate levels of leptin to overcome the state of leptin resistance observed in obese subjects particularly where insulin resistance is developed [30].

Previous studies have shown that in high fat diet- or high fructose/cholesterol diet-fed mice with SFN or SFN precurs or (glucoraphanin) a marked in body weight gain and plasma leptin concentration resulted [27]. Sulforaphane prevents cholesterol-induced lipid per-oxidation as the exposure to chol esterol doubled lipid peroxidation in Min6 cells. This was completely averted in the presence of $10 \mu \mathrm{M}$ SFN [31].

In a study conducted by Hoshida et al. [32], they found that hypercholes terolemia induced mi crovascular dysfunction characterized by loss of endothelium-derived nitric oxide.
However, the intake of dietary phase 2 protein inducers would ameliorate both hypertension and atherosclerotic changes by scavenging of superoxide a nion through the activation of nitric oxide [33]. Oral ingestion of broccoli sprouts, as a dietary source of SFN, protected smooth muscle cells from oxida tive injury by inducing cellular and mitochondrial antioxidants and phase-Il enzymes (superoxide dismutase, catalase, reduced gluta thione, glutathione peroxidase, glutathione reductase, glutathione-S-transferase, and $\operatorname{NADP}(\mathrm{H})$ quinone oxidoreductase) [34]. In a previous study conducted by Korish \& Arafah, [35], the ingestion of high dietary cholesterol resulted in a significant increa se in TC, TAG, LDL-c and VLDL-C, and decreased the HDL-c levels. Additionally, the res ults of the current work corroborate with those of Choi et al. [36], who found that mice fed on a high-fat diet plus $0.1 \%$ SFN for 6 weeks had low levels of total cholesterol and triglycerides. In a nother study by de Souza et al. [37], a significant lower levels of serum TAG were observed, however the supplementation of $0.5 \mathrm{mg} / \mathrm{kg}$ of SFN in the diet improved this alteration in serum lipid profile.

A study carried out by Pham et al. [38] illustrated the pres ence of two major pathways for cas pase activation; the death receptor and mitochondrial pathway consistent with known a mplification loop of the caspase pathways, confirming that sulforaphane acts within the death receptor pathway of caspase activation.

\section{Conclusion}

It can be concluded that SFN can produce a hypoglycemic effect on rats that suffered from insulin resistance, and could also have a hypolipidemic effect.

Table 3. Means \pm SEM Serum total cholesterol ( $\mathrm{mmol} / \mathrm{L}$ ), serum triacylglycerol ( $\mathrm{mmol} / \mathrm{L}$ ), serum HDL ( $\mathrm{mmol} / \mathrm{L}$ ) and serum LDL ( $\mathrm{mmol} / \mathrm{L}$ ) in rats received basal (Control), basal and Sulforaphane (Control $+\mathrm{SFN})$, high cholesterol high fructose (HCF), and high cholesterol high fructose supplemented with Sulforaphane (HCF + SFN) diets

\begin{tabular}{|c|c|c|c|c|}
\hline Group & $\begin{array}{l}\text { Serum cholesterol } \\
\text { (TC) } \mathrm{mmol} / \mathrm{L}\end{array}$ & $\begin{array}{l}\text { Serum } \\
\text { Triacylglycerol } \\
\text { (TAG) } \mathrm{mmol} / \mathrm{L}\end{array}$ & $\begin{array}{l}\text { Serum } \\
\mathrm{mmol} / \mathrm{L}\end{array}$ & $\begin{array}{l}\text { Serum } \\
\mathrm{mmol} / \mathrm{L}\end{array}$ \\
\hline Control & $2.36 \pm 0.07^{c}$ & $1.59 \pm 0.03^{c}$ & $0.89 \pm 0.02^{a}$ & $1.01 \pm 0.01^{c}$ \\
\hline Control + SFN & $1.62 \pm 0.08^{d}$ & $1.05 \pm 0.02^{c}$ & $0.63 \pm 0.05^{b}$ & $0.92 \pm 0.02^{c}$ \\
\hline HCF & $3.61 \pm 0.05^{a}$ & $5.94 \pm 0.30^{a}$ & $0.35 \pm 0.01^{c}$ & $2.99 \pm 0.06^{a}$ \\
\hline $\mathrm{HCF}+\mathrm{SFN}$ & $2.88 \pm 0.06^{b}$ & $2.79 \pm 0.25^{b}$ & $0.60 \pm 0.05^{b}$ & $1.92 \pm 0.18^{b}$ \\
\hline
\end{tabular}


Table 4. Means \pm SEM Hepatic reduced glutathione $(\mathrm{mg} / \mathrm{g}$ ), malondialdehyde ( $\mathrm{nmol} / \mathrm{g}$ ) and nitric oxide $(\mu \mathrm{mol} / \mathrm{g})$ in rats received basal (Control), basal and Sulforaphane (Control +SFN), high cholesterol high fructose (HCF), and high cholesterol high fructose supplemented with Sulforaphane $(\mathrm{HCF}+\mathrm{SFN})$ diets.

$\begin{array}{llll}\text { Group } & \begin{array}{l}\text { Reduced } \\ \text { glutathione (GSH) } \\ \text { concentration } \\ \text { (mg/g tissue) }\end{array} & \begin{array}{l}\text { Malondialdehyde } \\ \text { (MDA) } \\ \text { concentration } \\ \text { (nmol/g tissue) }\end{array} & \begin{array}{l}\text { Nitric oxide (NO) } \\ \text { concentration } \\ \text { (Kmol/g tissue) }\end{array} \\ \text { Control } & 4.44 \pm 0.587^{\mathrm{a}} & 7.17 \pm 0.965^{\mathrm{b}} & 4.73 \pm 0.962^{\mathrm{bc}} \\ \text { Control + SFN } & 4.31 \pm 0.193^{\mathrm{a}} & 3.77 \pm 0.443^{\mathrm{c}} & 4.63 \pm 0.691^{\mathrm{c}} \\ \text { HCF } & 1.77 \pm 0.587^{\mathrm{b}} & 12.08 \pm 0.775^{\mathrm{a}} & 9.00 \pm 1.431^{\mathrm{a}} \\ \text { HCF + SFN } & 5.10 \pm 0.588^{\mathrm{a}} & 7.52 \pm 0.559^{\mathrm{b}} & 13.41 \pm 1.850^{\mathrm{ab}}\end{array}$

In each column, means having different letters differ significantly

\section{Conflict of interest statement}

The authors declare that there is no any conflict of interest in the current research work.

\section{Permission of Animal Ethics Committee}

The current research work was approved by Research Ethics Committee, Faculty of Veterinary Medicine, Mansoura University.

\section{Authors' contributions}

Wael El-Shahat conducted the experiment and analytical procedures, Mohamed EL-Adl performed sample collection, sta tistical analysis, research writing and corres pondence for research, Mohamed Hamed conducted histopathological examination, and Youssef El-Saedy revised the manuscript and supervised the whole work.

\section{REFERENCES}

[1] Hao M, Head WS, Gunawardana SC, Hasty AH, Piston DW. Direct effect of cholesterol on insulin secretion: a novel mechanism for pancreatic $\beta$ cell dysfunction. Diabetes 2007;56:2328-38. https://doi.org/10.2337/db07-0056

[2] Zhao Y-F, Wang L, Lee S, Sun Q, Tuo Y, Wang Y, et al. Cholesterol induces mitochondrial dysfunction and apoptosis in mouse pancreatic beta-cell line MIN6 cells. Endocrine 2010;37:76-82. https://doi.org/10.1007/s12020-009-9275-y

[3] Bahadoran Z, Tohidi M, Nazeri P, Mehran M, Azizi F, Mirmiran P. Effect of broccoli sprouts on insulin resistance in type 2 diabetic patients: a randomized double-blind clinical trial. Int J Food Sci Nutr 2012;63:76771. https://doi.org/10.3109/09637486.2012.665043

[4] Tubbs E, Axelsson AS, Vial G, Wollheim CB, Rieusset J, Rosengren AH. Sulforaphane improves disrupted ER-mitochondria interactions and suppresses exaggerated hepatic glucose production. Mol Cell Endocrinol 2018;461:205-14. https://doi.org/10.1016/j.mce.2017.09.016

[5] Shawky NM, Shehatou GS, Suddek GM, Gameil NM. Comparison of the effects of sulforaphane and pioglitazone on insulin resistance and associated dyslipidemia, hepatosteatosis, and endothelial dysfunction in fructose-fed rats. Environ Toxicol Pharamacol 2019;66:43-54. https://doi.org/10.1016/j. etap.2018.12.008

[6] Wang Y-M, Zhang B, Xue Y, Li Z-J, Wang J-F, Xue C-H, et al. The mechanism of dietary cholesterol effects on lipids metabolism in rats. Lipids Health Dis 2010;9:4. https://doi.org/10.1186/1476-511X-9-4

[7] Deng J-Y, Huang J-P, Lu L-S, Hung L-M. Impairment of cardiac insulin signaling and myocardial contractile performance in highcholesterol/fructose-fed rats. Am J Physiol-Heart C 2007;293:H978-H87. https://doi.org/10.1152/ajpheart.01002.2006

[8] Gustafsson LL, Ebling WF, Osaki E, Stanski DR. Quantitation of depth of thiopental anesthesia in the rat. Anesthesiology 1996;84:415-27. https://doi.org/10.1097/00000542-199602000-00021

[9] Okulicz M, Hertig I. Acute sulforaphane action exhibits hormonal and metabolic activities in the rat: in vivo and in vitro studies. Czech J Anim Sci 2015;61:22-31. https://doi.org/10.17221/8665-CJAS

[10] Chevenne D, Letailleur A, Trivin F, Porquet D. Effect of hemolysis on the concentration of insulin in serum determined by RIA and IRMA. Clin Chem 1998;44:354-6. https://doi.org/10.1093/clinchem/44.2.354

[11] Allain CC, Poon LS, Chan CS, Richmond W, Fu PC. Enzymatic determination of total serum cholesterol. Clin Chem 1974;20:470-5. https://doi.org/10.1093/clinchem/20.4.470

[12] Lopes-Virella MF, Stone P, Ellis S, Colwell JA. Cholesterol determination in high-density lipoproteins separated by three different methods. Clin Chem 1977;23:882-4. https://doi. org/10.1093/clinchem/23.5.882

[13] Kerscher L, Schiefer S, Draeger B, Maier J, Ziegenhorn J. Precipitation methods for the determination of LDL-cholesterol. Clin Biochem 1985;18:118-25. https://doi.org/10.1016/S0009-9120(85)80093-X

[14] Fossati P, Prencipe L. Serum triglycerides determined colorimetrically with an enzyme that produces hydrogen peroxide. Clin Chem 1982;28:2077-80. https://doi.org/10.1093/clinchem/28.10.2077

[15] Finley PR, Tietz N. Clinical guide to laboratory tests: WB Saunders company; 1996.

[16] Woods AE. Laboratory histopathology: a complete reference: Churchill Livingstone; 1994.

[17] Beutler E. Improved method for the determination of blood glutathione. J Lab Clin Med 1963;61:882-8.

[18] Draper H, Hadley M. Malondialdehyde determination as index of lipid Peroxidation. Methods Enzymol 1990;186:421-431. https://doi.org/10.1016/0076-6879(90)86135-I

[19] Montgomery H, Dymock J. Nitric oxide assay. Analyst 1961;86:414-416.

[20] Dai C, Krantz SB. Interferon $\gamma$ induces upregulation and activation of caspases 1,3 , and 8 to produce apoptosis in human erythroid progenitor cells. Blood 1999;93:3309-3316. https://doi.org/10.1182/blood.V93.10.3309.410k04_3309_3316 
[21] Ho R. Handbook of univariate and multivariate data analysis and interpretation with SPSS: Chapman and Hall/CRC; 2006. https://doi. org/10.1201/9781420011111

[22] Prentki $M$, Nolan CJ. Islet $\beta$ cell failure in type 2 diabetes. J Clin Invest 2006;116:1802-1812. https://doi.org/10.1172/JCl29103

[23] Lu X, Liu J, Hou F, Liu Z, Cao X, Seo H, et al. Cholesterol induces pancreatic $\beta$ cell apoptosis through oxidative stress pathway. Cell Stres Chaperones 2011;16:539-48. https://doi.org/10.1007/s12192-0110265-7

[24] Vomhof-DeKrey EE, Picklo Sr MJ. The Nrf2-antioxidant response element pathway: a target for regulating energy metabolism. J Nutr Biochem 2012;23:1201-6. https://doi.org/10.1016/j.jnutbio.2012.03.005

[25] Collino M, Aragno M, Castiglia S, Miglio G, Tomasinelli C, Boccuzzi G, et al. Pioglitazone improves lipid and insulin levels in overweight rats on a high cholesterol and fructose diet by decreasing hepatic inflammation. Br J Pharmacol 2010;160:1892-902. https://doi.org/10.1111/j.14765381.2010.00671.x

[26] Zheng $\mathrm{H}$, Whitman SA, Wu W, Wondrak GT, Wong PK, Fang D, et al. Therapeutic potential of Nrf2 activators in streptozotocin-induced diabetic nephropathy. Diabetes 2011;60:3055-66. https://doi.org/10.2337/db11-0807

[27] Nagata N, Xu L, Kohno S, Ushida Y, Aoki Y, Umeda R, et al. Glucoraphanin ameliorates obesity and insulin resistance through adipose tissue browning and reduction of metabolic endotoxemia in mice. Diabetes 2017;66:1222-36. https://doi.org/10.2337/db16-0662

[28] Bahadoran Z, Mirmiran P, Azizi F. Potential efficacy of broccoli sprouts as a unique supplement for management of type 2 diabetes and its complications. J Med Food 2013;16:375-382. https://doi.org/10.1089/jmf.2012.2559

[29] Shawky NM, Segar L. Sulforaphane improves leptin responsiveness in high-fat high-sucrose diet-fed obese mice. Eur J Pharamcol 2018;835:108-14. https://doi.org/10.1016/j.ejphar.2018.07.050

[30] Paniagua JA. Nutrition, insulin resistance and dysfunctional adipose tissue determine the different components of metabolic syndrome. World J Diabetes 2016;7:483-514. https://doi.org/10.4239/wjd.v7.i19.483

[31] Carrasco-Pozo C, Tan KN, Gotteland M, Borges K. Sulforaphane protects against high cholesterol-induced mitochondrial bioenergetics impairments, inflammation, and oxidative stress and preserves pancreatic $\beta$-cells function. Oxid Med Cell Longev 2017;2017:3839756. https://doi.org/10.1155/2017/3839756

[32] Hoshida S, Yamashita N, Otsu K, Kuzuya T, Hori M. Cholesterol feeding exacerbates myocardial injury in Zucker diabetic fatty rats. Am J PhysiolHeart C 2000;278:H256-H62. https://doi.org/10.1152/ajpheart.2000.278.1.H256

[33] Wu L, Ashraf MHN, Facci M, Wang R, Paterson PG, Ferrie A, et al. Dietary approach to attenuate oxidative stress, hypertension, and inflammation in the cardiovascular system. Prod Natl Acad SciUSA 2004;101:70947099. https://doi.org/10.1073/pnas.0402004101

[34] Abellán Á, Domínguez-Perles R, Moreno DA, García-Viguera C. Sorting out the value of cruciferous sprouts as sources of bioactive compounds for nutrition and health. Nutrients 2019;11:429. https://doi. org/10.3390/nu11020429

[35] Korish AA, Arafah MM. Camel milk ameliorates steatohepatitis, insulin resistance and lipid peroxidation in experimental non-alcoholic fatty liver disease. BMC Complement Altern Med 2013;13:1-12. https://doi.org/10.1186/1472-6882-13-264

[36] Choi CY, Park K-R, Lee J-H, Jeon YJ, Liu K-H, Oh S, et al. Isoeugenol suppression of inducible nitric oxide synthase expression is mediated by down-regulation of NF-KB, ERK1/2, and p38 kinase. Eur J Pharamacol 2007;576:151-9. https://doi.org/10.1016/j.ejphar.2007.07.034

[37] de Souza CG, Sattler JA, de Assis AM, Rech A, Perry MLS, Souza DO. Metabolic effects of sulforaphane oral treatment in streptozotocindiabetic rats. J Med Food 2012;15:795-801. https://doi.org/10.1089/jmf.2012.0016

[38] Pham N-A, Jacobberger JW, Schimmer AD, Cao P, Gronda M, Hedley DW. The dietary isothiocyanate sulforaphane targets pathways of apoptosis, cell cycle arrest, and oxidative stress in human pancreatic cancer cells and inhibits tumor growth in severe combined immunodeficient mice. Mol Cancer Ther 2004;3:1239-48. 